\title{
Marital Rape in Nigeria: Appraising the information so far
}

\author{
Chidinma Ogba ${ }^{1}$ Kayode Adetifa ${ }^{2}$ \\ 1.Law Library, Ekiti State University, Ekiti State Nigeria \\ 2.Faculty of Law, Ekiti State University, Ekiti State Nigeria
}

\begin{abstract}
Marital union has the assumption of love, unity, conjugation, protection and approval by the society. Thus sexual relationships within the emblem of marriage are approved by law, society and God. Parties to marital union retain their basic human rights, however the assumption of unity in marriage makes it difficult to access human rights protection, in some countries, by women who are inherently vulnerable to harm and abuse. Marital union is viewed as the mechanism through which a husband gets licensed sexual satisfaction from his wife not minding the means it is obtained. This paper looks at the legality and morality of overlooking acts contravening human right laws, carried out within the ambit of marriage. It questions the legality of upholding marital unity while overlooking the abysmal mental and physical health issues carried out in marriage. This paper provides the conclusion that marital unity should be interpreted alongside with provisions of human right laws; while contradictory legal provisions should stand annulled by reason of its contradiction with human rights provisions. It was recommended that Nigerian laws on exemption of marital rape be reviewed and extended, by so doing partners would be made responsible for their actions in marriage.
\end{abstract}

Keywords: Marital Rape, Women Human Rights, Violence,

DOI: $10.7176 / \mathrm{JLPG} / 89-25$

Publication date:September $30^{\text {th }} 2019$

\section{Introduction}

The law of contract transfers rights and obligation within the ambits of the law, to contractual parties (The University of New Mexico, 2019); thereby ensuring that laws are not broken in a bid to reach agreements. According to Ruggie, as cited in Investment Treaty News (2011), the principles of responsible contract must include respect and full consideration of human rights provisions. Thus extant laws are always considered while drafting wordings of agreement. Marital union is within the ambit of contract law and is subject to inalienable human rights laws as entrenched in Nigerian constitution. Although Nigeria has domesticated human rights law under its constitution, ${ }^{1}$ however it is yet to domesticate the provisions of UN Declaration on the Elimination of Violence Against Women (DEVAW) which provides for the criminalization of marital rape (Rendall \& Venkatesh, 2016). ${ }^{2}$

Nigerian constitution makes provision for protection of fundamental human rights of people and within its chapter IV is the provision for protection of the right to life, freedom from discrimination and torture, freedom from forced labour except within the dictates of state law (The Constitution of the federal Republic of Nigeria, 1999). While entrenching general human rights laws, the provisions of international laws relating to women were cleverly left out while rights relating to children have found entrenchment in Child Rights laws. This is not surprising as Nigerian laws have a tendency to be patriarchal, protecting the exigencies of the male gender at the detriment of the female gender. Provisions of DEVAW, Convention on the Elimination of all forms of Discrimination Against Women (CEDAW), the International Covenant on Civil and Political rights (ICCPR) and different committees on human rights recognise and have entrenched violence including marital rape as criminal act (OHCHR, 2019; Rendall \& Venkatesh, 2016; UNFPA, 2006). The attendant health issues associated with marital rape was seen inherently as a threat to human right to life (OHCHR, 2019; Rendall \& Venkatesh, 2016; UNFPA, 2006). West (2017) asserts that criminalizing marital rape would be a breakthrough in understanding the provisions of human rights laws, nevertheless many states have intentionally stayed away from recognising it as a right while others have provided a leeway of escape such as a provision that a perpetrator can evade legal action where he marries his rape victim; therefore stating that rape cannot occur between two married people (Rendall \& Venkatesh, 2016). This has been popularly termed as "Marry your rapist law", a law that gives protection to rapist who end up marrying their victims. This law was the norm until the clamour for protection of women became popular and many countries specifically made provisions ending marriage as exoneration for

\footnotetext{
${ }^{1}$ Fundamental human rights as entrenched in chapter IV of Nigerian constitution are a reflection of international laws of human rights; the right to life and dignity of person are some of its basic provisions.

${ }^{2}$ It should be noted that Nigerian laws especially the Nigerian constitution has not shown equity and justice to its provision as it concerns women. The wording of Nigerian Constitution is extremely feminine. A male Nigerian citizen can transfer citizenship to his wife who is not a Nigerian by marriage but a female Nigerian citizen cannot do the same (Ss 25-32 of 1999 Constitution; Nigerian Citizenship Act, S.26 (1) (a)). The Nigerian penal code gives higher punishment for indecent assault on a male but lower punishment for a female victim. More so, for a male victim, it is assault but for female victim, it becomes misdemeanour, see Ss. 353 and 360 of the Nigerian Criminal Code and S.55(1) (d) Penal Code.
} 
rape victims (Jolly \& Raste, 2006). However before this, countries like Asia and Latin America practised it and gained their basis from the fact that an unmarried woman is the property of her father and so, where she is damaged, compensation has to be paid or the perpetrator takes the damaged property; thus marriage between two persons cannot incur criminal action as the woman has become the sole property of her husband. In 2016, Lebanon, in a bid to address marital rape entrenched a "marital right of intercourse" instead of criminalizing it (Rendall \& Venkatesh, 2016). Thus marital rape, a subset of rape evaded criminal status until the 19 th and $20^{\text {th }}$ century when certain countries began to augment it for other laws beneficial to women (Hasday, 2009). Countries were willing to allow property rights of women and passed law giving them such rights in a bid to evade criminalizing spousal rape (Hasday, 2000, p.1383); such property rights were seen as compensatory to women. Thus states were unwilling to recognise that a husband could rape his legally married wife since wives were seen by the society as properties of their husbands; initial properties of fathers transferred to husbands (Pracher, 1981).

The position of women in the society, culture and religion further contributed to the difficulty in recognising rape within marriage. The bible and Quran stipulate that a woman is subservient to her husband in all circumstances (Quran 4:34; Ephesians 5:25); which means that she must be obedient at all times. Husbands were admonished to love their wives just as Christ loved the church (Ephesians 5:25) while wives were advised to worship their husbands and submit to them as if they are submitting to God (Ephesians 5:22-24). Submission is tantamount to positions of a lord and a servant; the woman being the servant has no authority or right over her body, since the body does not belong to her ${ }^{1}$. Paul, one of the apostles of Jesus cautioned the church that women should not be seen to be heard in church, but to ask their husbands questions concerning church deliberations right at the quietness of their rooms (1 Corinthians 14: 34). In Islam, wives were also the properties of their husbands, to be loved and taken care of; and after their husband's death, inherit their properties; thus the position of Qawamah (Quaran 4:34). Thus the implication of marriage in religion is the exercise of dominion and authority by a husband over his wife; an implication that is presumed to have been known and understood by the wife and a view that seem to have permeated many societies that practise Christianity or Islam.

Nigerian Criminal and Penal Code which are reflections of the two major religions ${ }^{2}$ (Islam and Christianity) defines rape outside the purview of marital union (Nigerian Penal Code, s.282; Criminal Code, S. 357). The rationale of defining rape outside of marital relationship provided sanctity for marriage but legalised sexual violence within marriage. Thus a husband by reason of his strength and legal protection can abysmally exert violent power over his wife, in a bid to obtain sex. The exercise of authority to obtain sex from a wife was asserted as attached to marital contract which the wife has willingly signed (Hasday, 2009). Although marriage is seen as contractual, however it is types of contract that does not specify terms of agreement but leaves a blank paper to be filled in as the marriage persist. Despite this, the law of contract lends protection to parties and does not allow them to perform activities that go against their will and conscience (Pracher, 1981). The contents of contract also are always guided by extant laws of each society (Pracher, 1981). Thus marital relationship between a man and a woman should have the attention of the law and should not be seen as an enclave beyond its reach. It is logical that where contractual relationships are guided and monitored by extant laws, then no type of contract including marital one is to be excluded ${ }^{3}$. If sexual violence occurring within the enclave of marital union is overlooked, it then means that death occurring within the process of obtaining sexual satisfaction should also be overlooked, however this is not the legal position as right to life is not evoked only after death but within the life of a person. It then becomes difficult to understand why Nigerian laws have overlooked marital rape issues; though one can always argue that a partner under consistent marital rape can use such as a ground for dissolution of marriage. However this would have been an extreme measure as most partners in Nigeria would consider their children and their economic strength before delving into dissolution of marriage.

This paper looks at marital rape by analysing its implications on women's right to life, dignity, freedom from torture and discrimination, and right to reproductive health. This paper also looks at the position of the English Common law, extant Nigerian laws and religious laws on marital rape. Conclusion from reviewed literature is made and recommendations are provided.

\footnotetext{
${ }^{1}$ This does not however translate to the bible giving husbands right to rape their wives. In as much as the bible did not specifically address every issue of human life, however it makes provisions which when interpreted, solves issues of human life. It was clearly stated in Ephesians 5 vs $22-24$ that wives should be submissive and husbands should love their wives. Where there is love, there is no violence and so rape cannot occur. Although one could argue that many provisions in the bible were patriarchal, a reflection of the historical period and societal culture; however love was the command for husbands on their wives. When interpreted, it means that even as properties (wives) belonging to their husbands, they were to be treated with consideration of their feminine nature.

${ }^{2}$ They are reflections of the Biblical and Islamic Provisions in so far as they have given authority over a wife to the husband and portray patriarchy.

${ }^{3}$ The paramount thing to be considered is the life of the individual and not satisfaction of any religious, cultural or societal norm. After all many barbaric culture have been brought down in a bid to protect human rights of a group of persons.
} 


\section{Marital rape in the eyes of the law}

Hale's view that a husband cannot be criminally liable for raping his wife was generally held in the United Kingdom and interpreted as legal precedent until the landmark case of R vs. R(1991), in Crown Court where Owen J. in response to Hale's view on marital rape said that the statement was made at a time when marriage was indissoluble; and by 'obiter dictum' he provided interpretation of Hale's statement as "there would not have been a prosecution for many a long day despite any brutality which might have attended forcible sexual intercourse". Furthermore, by obiter dictum, he mentioned the case of R vs. Clarence (1888) where views were divided on whether a man can actually rape his own wife. While Wills Field and Al Smith JJ indicated that there were circumstances where a wife could be raped by her husband, Hawkins J, and ors said that it would be impossible since by marriage the wife has consented to sexual intercourse at any time and the fact that she is unwilling does not matter since her consent cannot be withdrawn except by the state.

In conclusion, Owen J. Held as follows:

....I cannot believe that it is a part of the common law of this country that where there has been withdrawal of either party from cohabitation accompanied by a clear indication that consent to sexual intercourse has been terminated, that does not amount to a revocation of that implicit consent. In those circumstances it seems to me that there is ample here both on the second exception and the third exception which would enable the prosecution to prove a charge of rape or attempted rape.

The above was a landmark case which established marital rape as a crime in England and Wales though the facts were on separation of marriage, but it acted as a pace setter to further rulings where marital rape was extended to spouses living together. Cases like:

1. R vs. C (1991), where Simon J. Ruled that " there is no marital exemption to the law of rape".

2. R vs. R (1992) as an appeal of R vs. R (1991); where Lord Keith of Kinkel in upholding the judgement in the lower courts ruled that "the fiction of implied consent has no useful purpose to serve today in the law of rape" and that marital rights exemption to rape was "a common law fiction" which had never been a true rule of English law.

The below stated countries followed suit on criminalisation of marital rape as follows:

a. North Carolina USA, 1993; The Nations High Commissioner for Human Rights established Marital rape as crime in 1993(Stephenson 2009).

b. Germany,1997; Turkey, 2005; though Turkey created only a civil remedy for victims, but did not criminalise it; Mauritius, 2007; Ghana, 1998/2007; Malaysia, 2007 and Thailand,2007.

c. Rwanda, 2009; South Korea, 2009 and Jamaica, 2009.

However in many other countries, it was difficult recognising marital rape as a crime. This was because of their societal norms, believes and cultures which were patriarchal. Some other countries were able to criminalise marital rape but were unable to effectively prosecute it (Kasai, 2018; World Bank, 2018); while others could allow the rapist marry the victim to evade criminal prosecution (Foreign Policy, 2017). Nigeria, a signatory to the Protocols on the Rights of Women in Africa, which protocol reinvigorates the African Charter on Human and People's Rights, is yet to domesticate the protocol as a Nigerian law (Ogunniran, 2009). This is because of the provision in the Protocol which abolished marital rights exemption in rape and made husbands criminally liable for raping their wives. Ogba (2010) assert that Nigerian laws, especially the constitutions of federal Republic of Nigeria, in its provisions are patriarchal, as its wordings and provisions portray male dominance over women. This provides explanation to why Nigerian penal and criminal codes which are supposed to find interpretation through the constitution do not (The Constitution of the Federal Republic of Nigeria, 1999, S.1). The interpretation of the fundamental human rights in Nigerian constitution means that any legal provision that exposes one to threat to life, threat to dignity of person, slavery or discriminatory to a person must stand annulled due to its contradiction to the constitution (Constitution of the Federal Republic of Nigeria, 1999). The right to life as enshrined in Nigerian Constitution (sec. 33(1) ) is not only interpreted positively when a human's life is no more but is a provision which is pre - activated to stop any harm before it happens.

Protagonist of marital rape exemption as stated in Hasday (2009) canvasses that though unwanted sex could be harmful to the victim but that marital intimacy could survive marital rape. They also opined that pursuing marital rape charges would halt any hope of reconciliation between spouses than would have been possible if they were left on their own to resolve the issue. Based on the above, they advocated for an alternative means to criminalisation of marital rape. Stephenson (2009) and Hurt (2010) in contradiction writes that marital rape should be handled seriously since it has more serious effect on the victim than ordinary rape. This is based on the fact that it was done in a marital home where harm is not supposed to come from and by one who is supposed to be the protector of the woman.

According to Nwogugu (1990), marriage is a right of 'consortium' which is a bundle of rights each spouse has over the other due to the incidence of marriage. Morrison (1997) calls it the natural law whereby the man 
acts in obedience to the law of nature. Thus a Pennsylvania court (Hasday 2009) says that criminalising marital rape is like going into the privacy of the bedroom to supervise the manner in which marital relationships are consummated. These views portray marital rape as a concept that is sacrosanct and cannot be meddled with. However Donnell (1995) has argued that human rights originate from the issue of man being first a human being; not excluding any class of man. One could rationalise that if spouses are allowed by Nigerian law to take one another to court on assault not involving sex , then there is no reason why rape which is already a criminal offence should not be extended to marriage in all countries, especially Nigeria. Although the criminalisation of marital rape in Nigeria and other countries does not mean that wives would make their husbands face criminal actions. This is because many women financially depend on their husbands, and know that institution of criminal actions against their husbands would likely mark the end of their financial dependence (Hasday 2009). Therefore, making women to be financially self dependent would be a first step to initiating campaign against marital rape exemption. Hurt (2010) stated that marital rape is a consistent action which makes a woman feel caged in the house because she has no hope of succour coming from any angle; she is also made to believe that she is the cause of her abuse and thus has not been a good and loyal wife as exhorted by her religion (Kareem, 2009). She is instructed to bury her feelings and submit to her husband despite the circumstance she finds herself. Therefore she is forced to live and have unlimited sex with a man whom she has lost respect and love for ; though she might see it as the sacrifice she has to pay in order to give her children and herself a home, and food to eat.

In Nigeria, violence against women comes into effect by acts of assault and battery (The Prohibition Against Domestic Violence Law of Lagos State, 2007). A violent act has no limitation in marriage; so husbands can be prosecuted for acts of violence against their wives. This means that the shade of the violence: that it was carried out in the process of sexual union between spouses holds no relevance. Since the penal code (S.282) and criminal code (S.357) exempted spouses involved in marital union from legal prosecution without specifically exempting them from violence, it could then be argued that separation could be made between the act of violence and sexual act. In this legal logic, violence is separated from rape; and the offender is prosecuted for violence.

The Nigerian Criminal and Penal code in their attempt to define rape succinctly denied married women their right to sexual consent (Nigerian Criminal code, S.357; Penal code, S. 282(1) (c)). Such rights been transferred to their husbands who they have contracted with. Thus they have no legal basis to determine their reproductive rights, or whether their husbands should use protection during sex or not; thus husbands therefore determine when their wives should be pregnant. These would be further implications of S. 357 of Criminal code and 282 (1) (c) of Penal code, thus the reason why reproductive right is not recognised in Nigeria. Okonkwo (1980) stated that the reason for the exemption of rape in marriage is to protect the unity and bond in marriage. In line with this, a wife is not criminally responsible and does not become an accessory after the fact by assisting the husband escape legal punishment. She is not also criminally responsible if in the presence of her husband and by his authority, she assists his confederates to escape legal punishment (Criminal Code Act, S. 10). Spouses are not criminally responsible for conspiring with each other (Criminal Code Act Sec.34; Keshiro V. IGP, 1955 56). Under S.163 of Evidence Act and S.83 of the Matrimonial Causes Act, husbands and wives are not compellable witnesses in respect of information known to them as it respects any of their spouses. This protection of unity and oneness in marriage even in the face of criminal actions cannot be equated with acts of violence which has the tendency to lead to death. The questions to be asked are these:

a. Do the spouses have equal strength and thus can defend themselves? Their unequal strength and lack of legal protection for the weaker strength is tantamount to discrimination and lack of equality. How would a country or state hand over to husbands the right to life and dignity of women simply because they are married? This amounts to abuse of fundamental human rights. Child Rights Acts were entrenched in different state laws because children were seen as humans of weaker strength, vulnerable to abuse and harm. Parents, especially mothers by nature are caregivers who are assumed to give their lives in protection of their children; and yet laws guiding how children are taken care of was entrenched and domesticated in Nigeria. It then becomes a concern why the state sees it as a difficult issue domesticating laws that guide the execution of marital contract, where women are not under the protection of their parents; at least, they should be under the protection of the state. The only explanation is what Ogba (2010) has termed as a patriarchal society and a patriarchal constitution. A constitution which inherently has power to nullify any law that goes contrary to its contents is been overlooked in relation to marital provisions in penal code, criminal code and its incidences. In the same way, many international laws pertaining to women, which are yet to be domesticated in Nigeria were passed because women have special needs and thus vulnerable to harm (Randall \& Venkatesh, 2016). Liberty both in marriage and outside marriage is a human right to life (Randall \& Venkatesh, 2016).

b. Do women have equal access to fundamental human rights of life, dignity with protection from slavery? 


\section{Religious provisions in respect of marital rape}

African tradition upholds polygamous marriage and concubine affiliation; but only for a man, whether married or not (Fenske, 2012). While a woman is mandated by tradition to be chaste, the same tradition, allows men to show their manliness by the number of women they date (Fenske, 2012; Lawson \& Gibson, 2018; Tertilt, 2006). This becomes a logical reason why criminalisation of marital rape in Africa should be positively considered as a wife would have the tendency to be exposed to life threatening diseases or be under such genuine fear. Her emotional health would also likely be frequently low especially where she is aware she is sharing her husband with another woman. In this instance, a law that mandates such wife to surrender her body in humility or by force, for marital consummation; would be tantamount to emotional torture, and a breach of fundamental human right to her dignity. In many parts of Nigeria, especially Northern States, Child marriages and of course forced marriages are still prevalent (Girls Not Brides, 2017). The prevalence is because tradition believes that the man can apply force in consummation of marriage and with time, the unwilling wife would cooperate. This norm is applied because there is no punishment for forceful and violent consummation; even though Nigeria ratified the "Convention on the "Elimination of All Forms of Discrimination Against Women" (CEDAW); and thus able to domesticate its provision, however this is yet to be done. Where marital rape is criminalised, marriage would only exist between two willing partners who love each other and willing to go into sexual union. Thus a law on marital rape would reduce the tendency of forced marriages and by extension child marriages.

The Holy Quran provision on submission is similar to that of the bible in Ephesians 5 vs. 25, which states that wives should be submissive to their husbands while their husbands should love their wives. In merging love and submission, it would be clear that there is no violence or force involved. However Abdullah Yusuf Alli (1997) states that the Quran admonishes husbands to spank their wives lightly, in order to obtain obedience from them. Thus, a husband who uses spanking to subject his wife to obedience of sex is following spiritual injunction. However the Christian sect admonishes married women to be submissive to their husbands (Ephesians 5 vs. 22) who in turn are admonished to love them with their lives (Ephesians 5 vs. 25). This if interpreted literally means that a husband should not do anything to hurt his wife; this means that husbands are not given any religious right to rape their wives but to show her love. It is quite logical that a woman being shown love would not deny the husband sex; this is where the problem lies; while one religion admonishes love and voluntary obedience, the other empowers the stronger partner to get submission. It would then seem that marital rape would not gain support in Nigeria until our religious books are interpreted rightly since they cannot be reviewed or changed.

\section{Conclusion}

Marital abuse cannot be excluded as being sacrosanct for no one was given a licence by God and nature to be abusive; abuse on its own is a crime; it cannot be set apart under the guise of marital union. If husbands are to be exempted from marital rape just because of marital union, then parents should also be immune from criminal acts as it relates to their own children whom they love and are responsible to. It is a general view that a mother cannot hate or abuse the child she gave birth to for she has been endowed with natural gift of love from God; however the state still comes in to monitor what happens within the home as it relates to child care. This logical view is the same with marital relationship. The state should not be oblivious of the fact that while there are good husbands, there are also the bad ones and their excesses needs to be curtailed. Laws have always been the medium for peaceful and humane co existence and are also considered during contract making. Laws do not prevent contract making but guide interaction and limit excesses, this same view should be applied in considering the domestication of marital rape in Nigeria and other African countries.

\section{Recommendation}

In view of the above, it is recommended that:

States should create a foundation for sensitization on marital rape issues as well as create effective measures channelled towards review of penal and criminal code to incorporate marital rape, bearing in mind the following attendant issues in marital rape:

a. How to establish a rape between spouses living together.

b. How to distinguish domestic violence within marital rape.

c. How to extract domestic violence entangled with marital rape.

d. How to provide economic dependence for women who depend on their husbands for their livelihood and thus might be unwilling to report marital rape (Meenakanit 2010).

e. How to effectively handle the after effect of marital rape as it relates to psychological wellbeing, societal norms and beliefs.

f. How to execute marital rape bearing in mind societal believes and norms. 


\section{References}

Abdullah, Y. A. (1997). “The meaning of the Holy Quran”. Amana Publication: USA.

Constitution of the Federal Republic of Nigeria. (1999). Chap. 4

Constitution of the Federal Republic of Nigeria, S.1

Corinthians, $1^{\text {st }} 14: 34$, King James Bible

Criminal Code Act, cap 89, Ss. 10, 34, 357

Donnelly, J. (1995). "Introduction to Human Right”. Information Agency: USA

Ephesians 5: 25, King James Bible

Ephesians 5: 22-24, King James Bible

Evidence Act. (2004). "Laws of the federation of Nigeria", Cap. E 14, vol. 6, S. 163

Fenske, J. (2012). “African Polygamy: Past and Present”. [online]. Available: https://www.dartmouth.edu

Foreign Policy. (2017). “The Rapists' loopholes: Marriage”. [online]. Available: http://foreignpolicy.com

Hasday, J.E. (2009). Protecting them from themselves- the Persistence of Mutual benefits for sex and race Inequality. [online]. Available: https:papers.ssrn.com

Hurt Hidden (2010) Domestic abuse Information. Marital Rape. [online]. Available: http://www.maritalrape.org

GirlsNotBrides .(2017). Child Marriage Rates. [online]. Available: https://www.girlsnotbrides.org/chilmarriage/nigeria

Investment Treaty News. (2011). Principles for responsible contracts: Integrating the management of human rights risks into state investors contract negotiation. International Institute for Responsible Development).

Jolly,S., Raste,M.S. (2006). Rape and Marriage: Reflection on the past, present and future. Journal of the Indian Law institute, 48(2), 277-284.

Kasai, T. (2018). Japan's Not-so-secret shame. [online]. Available: https://www.hrw.org

Lawson, D.W \& Gibson, M.A. (2018). Polygynous marriage and child health in sub-Saharan Africa: What is the evidence for harm? Demographic Research, 39(6).177-208. [online]. Available: https://www.demographicresearch.org/Volumes/Vol39/6/

Matrimonial Causes Act, Laws of the Federation of Nigeria (2004). S. 83

Morrison Wayne (1997). Jurisprudence. From the Greeks to Post Modernism. Cavendish Publishing Limited: London.

Ogunniran .(2007 - 2009) .Marital Submission: Extending the Frontiers of Marital Rape to Nigeria. Benin Journal of Public Law. University of Benin Nigeria: Benin. Vol. 5 - 7.

OHCHR. (2019). International human rights law framework regarding gender stereotyping. [online]. Available: https://www.ohchr.org

Ogba, C.O. (2010). Nigerian constitution and its bias nature: discriminatory Provisions against women in the 1999 constitution of the Federal Republic of Nigeria. African Journal of Arts and Cultural Studies, 3 (1), $132-137$

Okonkwo, C.O. (1980). Okonkwo and Naish on Criminal Law in Nigeria $2^{\text {nd }}$ ed, Ibadan: Spectrum Books, 271.

Penal Code, S.282 (1) (2)

Pracher, M .(1981). The Marital rape exemption: A violation of woman's right of privacy. Golden Gate University Law Review, 11(1). https://digitalcommons.law.ggu.edu/ggulrev/vol11/iss3/1/

The Prohibition Against Domestic Violence Law of Lagos State. (2007). A Law to provide

protection against domestic violence and for connected purposes. Supplement to Lagos State Official Gazette Extraordinary No.53, Vol.40 of $30^{\text {th }}$ July 2007.

Quran 4:3. Retrieved May 22, 2019 from: https://quran.com/4/3

R v. Clarence (1888) 22 QBD 23

R v. R. (1991) UKHL 12

R v. R (1991) 3 WLR 767

R v. R (1992)1 AC 599

Rendall, M \& Venkatesha,V. (2016). Symposium on the international legal obligation to criminalise marital rape: criminalising sexual violence against women in intimate relationships: State obligation under human rights. https://eprints.soas.ac.uk

Stephenson, K. (2009). Spousal Sexual Assault is a Human Right Violation. http://www.sexual.abuse.suite101.com/article/

Tertilt, M. (2006). Polygyny, Women's Rights and Development. Journal of the European Economic Association, 4(2-3), 523-530.

Tijani, N. (2007). "Matrimonial Causes in Nigeria Law and Practice”. Rennaissance Law Publishers Limited: Lagos.

UNFPA. (2006). The human rights of women. Retrieved February 23, 2019 from https://www.unfpa.org

Wrapa Newsletter (April - June 2002) Eliminating Violence against Women - The Legislative Approach. 3 (1)11. [online]. Available:https://pdfs.semanticscholar.org 
West, R. (2017). Marital rape, consent, human rights: Comment on "Criminalizing sexual violence against women in intimate relationships. https://doi.org/10.1017/s2398772300001434

World Bank. (2018).Legislation explicitly criminalises marital rape ( $1=Y e s, \quad o=N o)$. [online]. Available: https://www.data 